\title{
A continental forest policy for North America?
}

\author{
by William L. Wagner ${ }^{1}$
}

\begin{abstract}
Changes in the global forest economy along with moves in the priorities in the management of American federal forests may have created a timber supply condition that has hampered trade relations with Canada over softwood lumber. Concurrently, agents of natural disturbance are impacting significant areas of North American timberlands. Current institutional arrangements, including those initiated by the Softwood Lumber Export Charge Act of 2006, may be encouraging less than optimal cooperation. A non-profit, partially governmental collaborative approach termed the continental forestry chamber is proposed as an alternative arrangement in resolving forest conservation, management and trade issues in North America.
\end{abstract}

Key words: conservation, management, softwood lumber, deliberative democracy

\section{RÉSUMÉ}

Les changements dans l'économie forestière mondiale ainsi que les modifications des priorités de l'aménagement des forêts fédérales états-uniennes peuvent avoir engendrer une situation au niveau de l'approvisionnement en matière ligneuse qui a entravé les relations commerciales portant sur le bois d'œuvre résineux du Canada. Au même moment, des agents de perturbation naturelle affectent de vastes territoires forestiers de l'Amérique du Nord. Les accords institutionnels actuels, y compris ceux mis en place par le Softwood Lumber Export Charge Act de 2006, pourraient établir une coopération inférieure aux attentes. Un organisme de coopération, en partie gouvernemental et sans but lucratif, qui pourrait porter le nom de chambre continentale de foresterie, est proposé en tant que mesure alternative de résolution des enjeux de conservation des forêts, d'aménagement et de commerce international en Amérique du Nord.

Mots clés : conservation, aménagement, bois d'œuvre résineux, démocratie délibérante

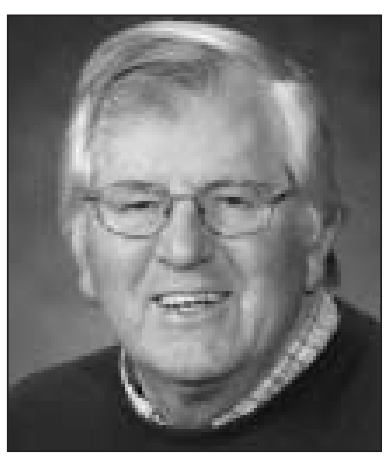

William L. Wagner

\section{Introduction}

President Theodore Roosevelt opened a May 1908 conference of governors at the White House by acknowledging that "The conservation of natural resources is the fundamental problem. Unless we solve that problem it will avail us little to solve all others (Pinchot 2001)." At that conference Roosevelt introduced Chief Forester Gifford Pinchot's formulated policy for the conservation of natural resources. Conservation in Pinchot's sense was about the protection, preservation and wise use of the natural resources of the earth. It was not a series of separate and independent tasks but one single problem. It was a profound idea at the time and was to prove very important throughout the rest of the century.

The need for a North American policy on natural resources and institutional instruments for their conservation first gained international attention a year later. Under the leadership of TR Roosevelt and Gifford Pinchot, a North American Conservation Conference was organized in 1909 and was held in Washington with representatives from Canada, Newfoundland, United States and Mexico in attendance. Roosevelt opened the conference with the observation, "It is evident that natural resources are not limited by the boundary lines which separate nations, and that the need for conserving them upon this continent is as wide as the area upon which they exist (Pinchot 2001)."

Pinchot (2001) restated one of Roosevelt's principles in 1940 when he wrote, "No nation is self-sufficient in essential raw materials. The welfare of every nation depends on access to natural resources from other nations, which it lacks. Fair access to natural resources from other nations is therefore an indispensable condition of permanent peace." Thus, Pinchot saw "fair access" through trade as an important principle of conservation. He then suggests the formation of a Commission for the purpose of representing all the American nations in the gathering of information concerning natural resources in the respective American countries. He saw the Commission formulating a plan and recommendations "to the American governments for a general policy and a specific programme of action." He suggested that the Commission collect facts concerning the "origin, destination, and quantities of imports and exports; present barriers to fair access; and sources of pressure upon nations to acquire natural resources." While he could not foresee that in the late 1950s

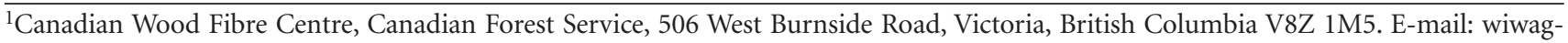
ner@nrcan.gc.ca 
the Food and Agriculture Organization of the United Nations would establish a North American Forest Commission, which, for the most part, ignored trade and concentrated on technology, he did predict disputes in trade if such a commission was not established. Pinchot (2001) thought that "Such a Commission would be of immense and lasting value to the American nations...in addition to opening a road toward a workable basis for permanent peace."

Since it is important to understand the economic and institutional context of the resource, after a brief introduction to the institutional context of forestry in western North America, much of the rest of this paper revolves around the issue of trade, generally, and softwood, specifically. The idea of power will be introduced and, briefly, its sources will be presented. The paper will then review various institutional instruments to resolve disputes in North American natural resource conservation and trade. It concludes by arguing for the inclusion of a type of deliberative democracy in the terms of reference of a new North American chamber that insists decisions be based, after due deliberation, on what is best for North America as a whole rather than those of one country alone.

\section{Discussion}

Forestry in Canada and the United States had its roots in European traditions that were transferred largely unchanged to North America. This proved problematic for at least two reasons. First, European forests had been under management for centuries. While having an age distribution of trees closely approximating the ideal area for each age class, very old natural forests were largely absent from the European landscape. The Forest Services in both United States and Canada set out to remodel the largely old, uneven-aged North American forests to fit the European model of balanced age and area distributions. Leaders like Pinchot in the United States and Fernow in Canada were engaged in bringing the "Gospel of Efficiency" to North America and rejected ideas from thinkers like John Muir in creating "forestry" in North America (Hays 1959).

About 80 years into the process of bringing regulation to the federal public forests in the United States, modern foresters ran into another environmental movement with an Endangered Species Act to serve as a weapon to conserve and protect old forests. The result was that in 1993 a comprehensive plan was initiated to end the impasse over management of federal forest lands in the Pacific Northwest within the range of the Northern spotted owl. Further, the Interior Columbia Basin Ecosystem Management Project was initiated in 1993. Large areas were withdrawn from traditional forestry and annual yields from public forests were significantly reduced.

Secondly, $19^{\text {th }}$ century Europe did not grow enough wood to meet its own needs; thus, the demand for European timber was nearly constant and could be adjusted by varying imports. Clawson (1985) argued that the theories developing from this situation focused on supply issues and almost ignored wood demand in the formulation of rotations, annual cuts and forest tenure arrangements. Supply of forests for products is apparently at the foundation of policy in Canada and especially in British Columbia.

Another factor that plays a role in forest policy has to do with Forest ownership. In Mexico more than $80 \%$ of the for- est lands are community owned, $15 \%$ are held in private while the federal government holds about 5\%. ${ }^{2}$ German forests are about 54\% public while in France about 25\% are public. In the United States, about $60 \%$ of the western forests and about $71 \%$ of all American forests are privately held (Smith et al. 2000). Western Canada is primarily made up of public forest lands; less than 5\% of the forests of BC are private. This means that while the implementation of public forest policies is important to the well-being of companies and communities in the United States, Germany and France, there are private sector alternatives. Public forest policies are critical in western Canada and Mexico. Misunderstanding of the purpose and economic impacts of these policies is one of the basic reasons Canada and the United States have become engaged in the softwood lumber dispute.

Today, forestry is based on what the early foresters thought about North American forests and gleaned from teaching and experiments in Europe. They created a mythology, a mythology that formed the basis for the development of forest institutions in both the United States and Canada. Sustained yield, even flow, allowable cut effect and sustainable communities are ideas all derived from an unchanging world. Many western North American forest management and protection policies are based in the assumption of no change or the idea of equilibrium. Lodgepole pine, for example, was to be kept to a forester's rotation of 125 years. Forests and civilizations are constantly changing. But climate change, warmer winters, bark beetles and fire each suggested that change in stand dynamics before 80 years was the normal condition for lodgepole pine (Baumgartner et al. 1985).

\section{Forests and Forest Policy}

Managed forests are archives of values and culture. Yet, forest policy has historically been thought of largely in terms of economic value - trees of wood for energy and construction and the role of primary production in creating capital for regional economic development (Westoby 1987). These traditional notions are giving way to new approaches that focus on forest ecosystems and broader questions of forest composition and structure, as well as energy and materials flows through forest systems. Still, the so-called "ecosystem-based" approach to forest management can be somewhat sterile as it ignores the people living in or associated and dependent upon forests.

The purpose of a society's forests is outlined in its forest policies that often legitimize activities and uses that can be undertaken. Scientists and professionals are tasked with creating a vision based on the economic, ecological and institutional context of the resource. This vision is often blurred by uncertainty and flawed; limited or incorrect information is sometimes used to create choices for policy-makers. Thus, policies need institutional arrangements that require continual refinement as the context in which they were developed changes.

There is little doubt that American federal forest management has recently shifted. The regulated forest with its European roots has given way to ecosystem management (Perry 1998). Does this shift represent a move to incorporate science into the discussion about long-term sustainability of

${ }^{2}$ http://www.fs.fed.us/global/nafc/2002/meeting_info/technical_ papers/criteria_indicators.doc Accessed June 13, 2007 
public forests or is it just adoption of a new mythology, a preservationist view that seeks to minimize human-caused change and accepts "nature is best" without question?

\section{The North American Forest Commission}

The Food and Agriculture Organization of the United Nations (FAO) created the North American Forest Commission (NAFC) as one of six regional forestry commissions in the world. The NAFC was established in 1958 to provide a policy and technical forum for Canada, Mexico and the United States to discuss and address forest issues on a North American basis. It is comprised of the federal forest services of the three countries.

NAFC supports research and natural resource management activities through seven working groups. These working groups include atmosphere change, fire management, forest products, insects and diseases, silviculture, forest inventory and monitoring, and forest genetic resources. At its $22 \mathrm{nd}$ session, the NAFC agreed to undertake an evaluation to objectively assess NAFC's strengths and weaknesses in carrying out its mandate and to provide suggestions for strengthening its performance and influence and enhancing its effectiveness ${ }^{3}$. It was asked to:

- Evaluate the success of the NAFC in meeting its mandate to "provide a policy and technical forum for Canada, Mexico and the United States to discuss and address forest issues on a North American basis;

- Evaluate the impact of the NAFC on the forest policy of its three member countries;

- Evaluate the success of the NAFC working group in meeting their mandates;

- Determine if current activities of the working groups are concentrating on priority issues for the three NAFC countries;

- Assess the role of the Bureau of Alternates (BOA) in providing guidance to the working group and strategic advice to the Commissioners; and

- Evaluate if the impact of NAFC is justified by its cost. An external consultant from Canada led the evaluation, assisted by representatives of each NAFC member country. The evaluation included extensive interviews and a comprehensive review of NAFC documents. The Evaluation Report was finalized in July 2006 and made available to the NAFC countries in English and in Spanish.

\section{Key Findings}

- NAFC has a minimal impact on forest policy in the three countries.

- NAFC has been successful as a technical forum. Most working groups have made valuable contributions to their subject areas.

- Most working groups work from the bottom-up; little guidance is provided to the working groups from the Commissioners or from the Bureau of Alternates. The Bureau of Alternates is not effectively guiding or monitoring the work of the working groups.

- Costs to member countries of participating in NAFC are relatively modest.

${ }^{3}$ The evaluation report can be accessed at ftp://ftp.fao.org/ docrep/fao/meeting/011/ah489e.pdf. Accessed April 4, 2007.
Given the composition of the Commission and the fact that the three federal forest services have few policy-making powers individually-let alone collectively-it is not surprising that the NAFC has had little policy impact.

\section{The Idea of Power}

At the basic level, power is the ability to influence the behaviour of others to achieve desired outcomes. The concept of power has both military and economic relevance. The two types of power are related. With wealth, a country can purchase a large and strong military-at least as long as its citizens are willing to accept the costs and social trade-offs of financing the military. Yet, the two types of power can also exist independently. Julius (2005) uses Japan in the 1980s as an example of an economic superpower with a weak military.

While the notion of power has largely been absent in contemporary economic theory (Rothschild 2002), two economists, Deanne Julius (2005) and John Kenneth Galbraith (1985), have written on the subject of economic power. Julius discusses five types of economic power. She also discusses Joseph S. Nye's concept of "soft power" as it applies to a country's economic aims. Galbraith discusses the anatomy of power through property, organization and personality as its sources.

Neither Canada nor Mexico can compare with the United States in terms of wealth, a component of property. Fig. 1 compares the gross domestic product of the various states with countries in the world. In 2001, Canada had an economy about the size of that of Texas while Mexico's economy was equivalent to that of Illinois in size. Canada is a very tradedependent country while the United States is one of the least. Simply, the American market is more important to Canada than the Canadian market is to the United States. This is the reason that Canada approached the United States and formally proposed the negotiation of a free trade agreement with the Americans. Canada's motive was to secure guaranteed access to American markets at a time of rising protectionism. Canada wanted the Americans to eliminate tariffs and also gain exemption from American trade remedy laws based on some agreement on subsidies between the two countries.

The United States responded that free trade in goods was acceptable, provided that (a) it retained the power to decide what trade practices were fair, and (conversely) what Canadian policies unfairly subsidized exports, (b) the concept of open borders should apply also to services and to investment, (c) American producers should have access to Canadian natural resources, notably energy resources, on an equal basis with Canadian producers, and (d) various irritants, including some features of a 1965 sectoral agreement on automobiles, be removed (Leslie 1997). In the end, the United States retained the ability to amend its trade remedy legislation, although it did agree to binding arbitration regarding the administration of the trade remedy.

Chief among the impediments to integration of the North American economies are unilateral trade actions that result in the distortion of trade and investment and hamper business strategies seeking to improve productivity across the region. American-Canadian bilateral economic initiatives like the Free Trade Agreement of 1989 and the subsequent North American Free Trade Agreement suggest that negotiated approaches to conflict resolution are more constructive than unilateral activities. 


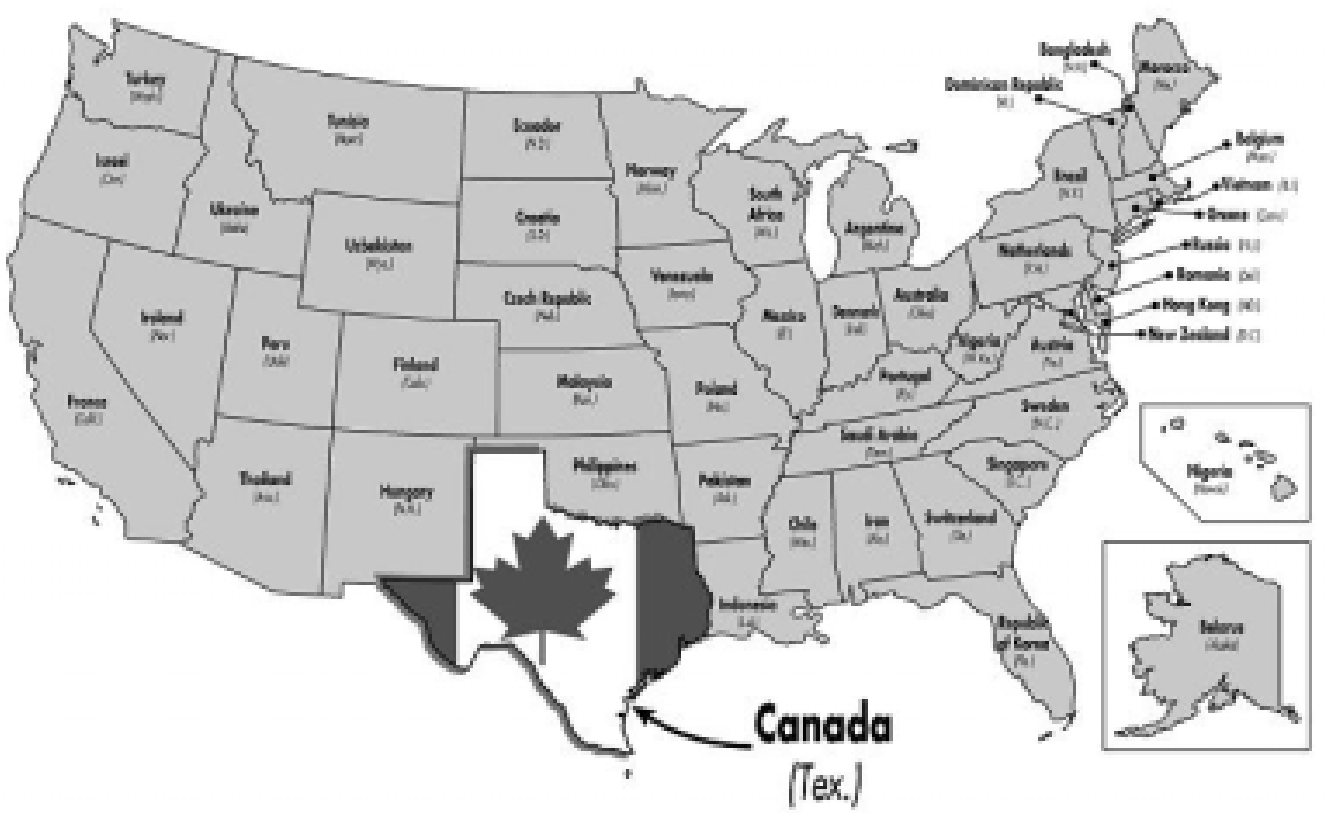

Fig. 1. Comparison of GDP of various states and countries in the world - 2001.

Source: Bill Wilson, Director, Industry, Trade, and Economics and Trade Program, Natural Resources Canada - Canadian Forest

Service, Pacific Forestry Centre, personal communication.

The North American Free Trade Agreement attempts to bring together three federal states in an economic partnership among three countries, each of which is a federation based upon different historical principles in their approach to the division of power. For example, in Canada federal spending power has performed a similar function as the commerce clause in the American constitution for expanding federal jurisdictions. What is so interesting about the question of federalism is that it provides opportunities to change institutional structures in this continental economic partnership.

Yet, given the power setting of the three federations, a troubling concern in Canada is whether closer economic ties with the United States will reduce the ability of Canada to adopt policies that reflect distinctive national preferences, especially for their public forest lands. This concern was well illustrated in the recent conflict over trade in softwood lumber and the Department of Commerce's 2003 proposal for an analytical framework for softwood lumber from Canada and requisite changes in provincial timber policies in a failed attempt to get relief from duties and tariffs (DOC 2003).

Under current institutional arrangements, in negotiations with the United States on economic issues, can Canada and Mexico receive anything close to parity? If the goal is a lasting and fair agreement on continental forest conservation, management and trade in wood products, new ideas need to be entertained that reduce the adversarial nature of discussions among the three North American nations. At the centre of deliberative theory is that the decision-making process becomes legitimate and generates better results if people affected by the decisions are involved in shaping them. It only makes sense that a decision-making process that is shared between institutions and people affected by the decisions and guided by rationality instead of coercion should work better than the current system. ${ }^{4}$

\section{Trade - The Softwood Lumber Disputes}

In terms of trade in forest products, relations between the United States and Canada seem to always have been stressed. One of the first trade disputes between the two countries occurred in 1839 with the Aroostook Lumber War. It was a bloodless war whose end was negotiated by Secretary of State Daniel Webster and Lord Ashburton. The WebsterAshburton Treaty gave over 7000 square miles of the disputed area, including the Aroostook Valley in Maine, to the United States, and several critical waterways, including the all-important east-west passage of the St. Johns River, were opened to free navigation by both countries. Essentially, the Treaty served as a precedent for peaceful settlement of disputes between the United States and Canada through diplomacya critical issue given the length of the shared border. $^{5}$

The opening salvos of the present dispute were fired on October 7, 1982, when the Coalition of Fair Lumber Imports, a group that consisted of companies that owned large areas of industrial forest lands, first petitioned against Canadian softwood lumber imports under American countervailing duty

\footnotetext{
${ }^{4}$ For more on this subject, see "Policy advice for public participation in British Columbia forest management” by C. Tyler DesRoches in this issue.

${ }^{5}$ http://www.yale.edu/lawweb/avalon/diplomacy/britain/br-1842. htm and http://www.u-s-history.com/pages/h357.html. Accessed June 18, 2007.
} 
law, alleging that various forest management practices in Canada were providing subsidies to Canadian manufacturers, producers and exporters. The dispute was to last some 24 years and distort the nature of trade in softwood lumber products in North America. Because of changes in American trade law, trade issues have become extremely complex. Legal expertise was retained to argue various positions before the World Trade Organization and those tribunals created by the Free Trade Agreement. Yet, the softwood lumber dispute elevated to a point almost beyond comprehension. In the first stages of the current dispute, only one law firm represented both Canadian industry and government. By 2003, more than 40 law firms worked for the Canadian side with legal costs estimated to be $\$ 50$ million annually during the last phase of the dispute (Campbell 2005).

December 30, 1986, marked the conclusion of the first stage of the dispute when Canada and the United States signed a Memorandum of Understanding (MOU). With the signing of the MOU, Canadian provinces were required to collect a 15\% tax on American-bound softwood lumber. On January 2, 1988, Canada and the United States entered into the Free Trade Agreement. Article 2009: Softwood Lumber stated that:

"The Parties agree that this Agreement does not impair or prejudice the exercise of any rights or enforcement measures arising out of the Memorandum of Understanding on Softwood Lumber of December 30, 1986."

In September 1991, Canada notified the United States that it would terminate the MOU on October 4. After placing provisional duties on Canadian lumber, the U.S. launched a countervailing duty investigation. In March 1992 the International Trade Administration ruled that a provisional duty of $14.48 \%$ was to be imposed. This figure was subsequently revised in May of that year to $6.51 \%$. In December 1994, the U.S. agreed to return all deposits collected and the two countries started a "consultative mechanism" to discuss areas of concern regarding the forest industry.

In April 1996, an agreement was reached between the two countries that permitted the exportation of 14.7 billion board feet of lumber to the United States without penalty. When more than 14.7 and less than or equal to 15.35 billion board feet was exported to the United States there would be a penalty of US\$50 per thousand board feet. Amounts of lumber in excess of 15.35 billion board feet would pay US\$100 per thousand board feet. Another feature of the agreement was that additional volumes (92 million board feet) beyond the quota would be allowed to be exported when a certain or "trigger" price was met or exceeded. ${ }^{6}$

Research presented in Table 1 suggests that the American consumer was not only financing the dispute but that various American forest companies gained financially through political means rather than through making improvement in their manufacturing facilities. The countervailing duty and quota only aided the American forest industry in domestic markets; it would not aid them in becoming competitive in the global market.

\footnotetext{
${ }^{6}$ Foreign Affairs and International Trade Canada. http://www. dfait-maeci.gc.ca/eicb/notices/ser92_1-en.asp. Accessed June 15, 2007
}

Table 1. Financial implications of two stages of the softwood lumber dispute

MOU (Wear
and Lee 1993)

\begin{tabular}{lll}
$\begin{array}{l}\text { Estimated market } \\
\text { lumber price }\end{array}$ & $\begin{array}{l}\$ 19.90 \\
(1982 \$ / \mathrm{mbf})\end{array}$ & $\begin{array}{l}\$ 59.05 \\
(1997 \$ / \mathrm{mbf})\end{array}$ \\
$\begin{array}{l}\text { US producer } \\
\text { surplus }\end{array}$ & $\begin{array}{l}\$ 2632.4 \\
(1982 \text { mill } \$)\end{array}$ & $\begin{array}{l}\$ 7738.8 \\
(1997 \text { mill } \$)\end{array}$ \\
$\begin{array}{l}\text { US consumer } \\
\text { surplus }\end{array}$ & $-\$ 3789.5$ & $-\$ 12485.8$ \\
\hline
\end{tabular}

Fig. 2 traces the price of softwood lumber under the countervailing duty, no duty and the quota under the Softwood Lumber Agreement (SLA) through time. The figure seems to verify economic trade theory that trade barriers can raise prices even when confronted with a static demand. Price is artificially held at higher levels than what would occur in a competitive market. Importantly, increased prices may attract new exporters and product substitutes into the North American Softwood market.

The softwood dispute largely ignored real changes that have taken place both in the American and global forest products' markets. For example, the annual timber harvest in the Northwest fell 50 million $\mathrm{m}^{3}$ between the years of 1988 and 1998. The decline in harvest was largely a result of the Northwest and Columbia Basin Plans as well as the move to ecosystem-based management on federal lands. In the southeast between 1953 and 2001, 15.9 million acres of southern pine timber were converted to hardwood. Untold acres were also converted from saw timber to pulpwood to support the pulp and paper industry (South and Buckner 2003).

Xiang and Yin (2006) highlight some of the impacts of globalization along with American policy change on softwood lumber trade. In 2004, the United States was both the world's largest importer and producer and the second largest exporter of wood products. Xiang and Yin (2006) note that the U.S. is the world's largest softwood lumber market and that during the last 15 years more than $90 \%$ of the American imports of softwood lumber came from Canada. During the years of the softwood lumber dispute not only were economic conditions in the domestic forest sector changing, but the global forest sector was also under stress. For example, the Asian financial crisis occurred at a time when the American government was curtailing harvests from national forests to protect endangered species.

Importantly, the American dollar continued to gain strength against many other currencies exporting lumber into the United States. In international markets, a strong currency makes foreign products cheaper and domestic products more expensive, exposing domestic producers to greater market competition. McCarl and Haynes (1985) suggest this was the major factor in increased Canadian share of the United States' and Japanese markets and the decreased American forest product exports to Japan. 


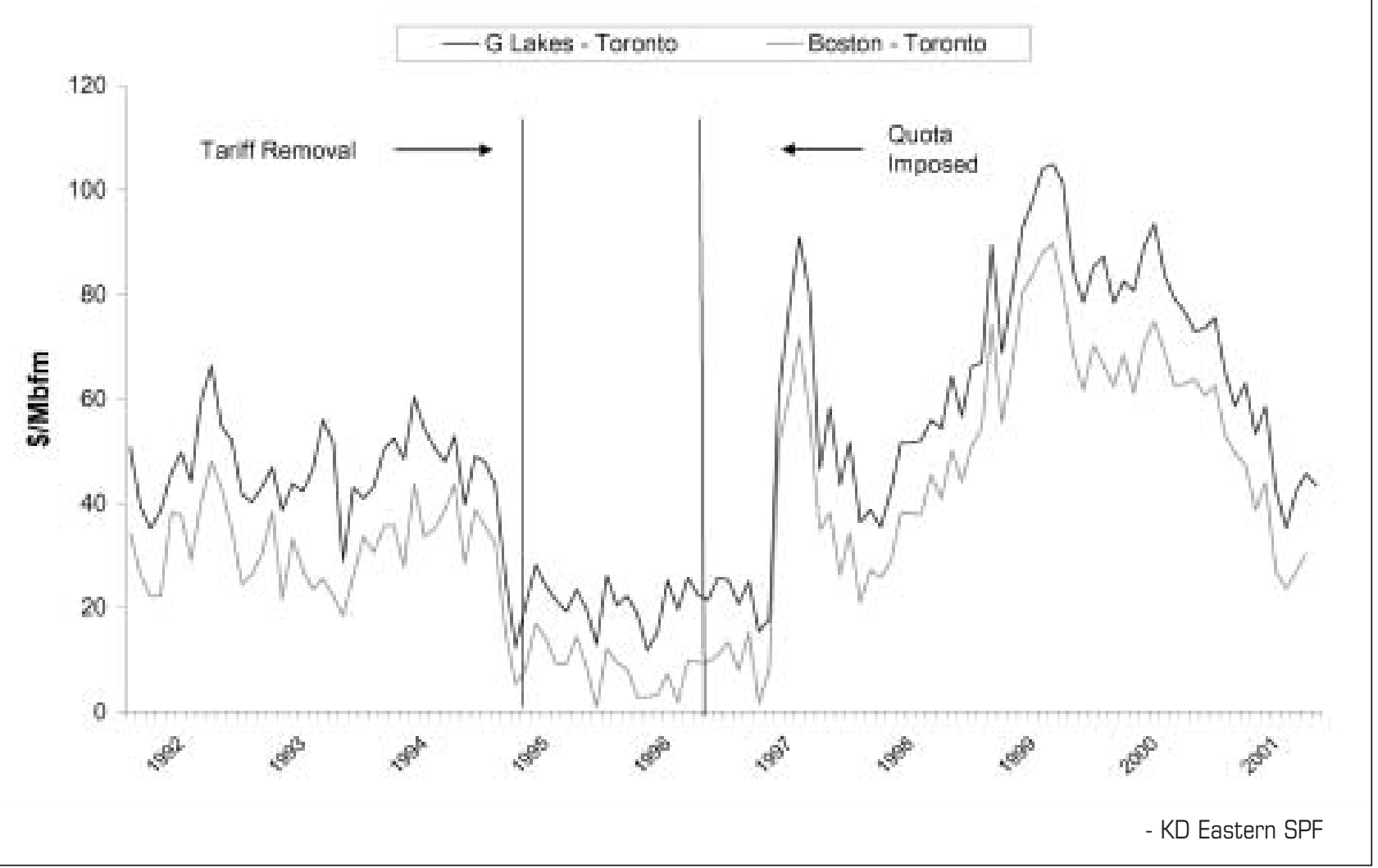

Fig. 2. Price wedge between US (Great Lakes) and Canadian (Toronto) markets Source: Stennes and Wilson 2005.

\section{North American Free Trade Agreement}

Midway through the softwood lumber dispute the North American Commission for Environmental Cooperation (CEC), the environmental side agreement of the 1994 North American Free Trade Agreement (NAFTA), was formed to address issues of mutual concern including trade. The preamble reaffirms "the sovereign right of States to exploit their own resources pursuant to their own environmental and development policies and their responsibility to ensure that activities within their jurisdiction or control do not cause damage to the environment of other States or of areas beyond the limits of national jurisdiction. ${ }^{7}$ With this affirmation, the CEC's role seems more one of environmental governance than developing policy.

The central institution of the NAFTA is the Free Trade Commission. It supervises the implementation and further elaboration of the Agreement and helps resolve disputes arising from its interpretation. The Free Trade Commission then aids in the governance of trade. It also oversees the work of the NAFTA's Committees, Working Groups and other subsidiary bodies. What NAFTA does not do is create any common institutions that develop policies and institutional arrangements for the conservation or the use of North American natural resources. What it does offer is conflicting economic and environmental argumentation promoting current resource policy. Chapter Six, Energy and Petrochemicals, Article 608.2 states: "the Parties agree to allow existing or

$\overline{7 \text { http://www.cec.org/pubs_info_resources/law_treat_agree/naaed }}$ naaec01.cfm?varlan=english. Accessed April 2, 2007. future incentives for oil and exploration, development and related activities in order to maintain the reserve base for these energy resources." NAFTA then perpetuates subsidies. Fossil fuel subsidies bias the market against alternatives. Subsidies in this non-renewable sector are usually counterproductive and often damaging to both the environmental and the economy (Roff et al. 2003).

\section{Softwood Lumber Export Charge Act of 2006}

In 2004, the CEC announced its new priority areas for its Trilateral Cooperative program with one being trade and another being the environment. Within two years, the United States and Canada signed the Softwood Lumber Agreement of 2006 (SLA 2006) resulting in Canada's Softwood Lumber Export Charge Act of 2006. The agreement established institutions and institutional arrangements that appear to duplicate or negate the work of the CEC as far as trade in softwood lumber is concerned. As the terms of the SLA 2006 were on the drafting table, the CEC was investigating allegations of logging destroying thousands of migratory bird nests in Ontario's forests and the discharge of toxic effluent from eastern Canadian pulp and paper mills. On February 5, 2007, the secretariat of CEC publicly released factual records alleging that Canada had failed to effectively enforce its environmental law in relation to clearcut logging. Specifically, the documents alleged that Canadian logging operations had destroyed over 45000 migratory bird nests in central and northern Ontario during the nesting season in the summer of 2001. They also accused Canada of failing to effectively enforce the pollution prevention provisions of the Fisheries 
Act and provisions of the Pulp and Paper Effluent Regulations against pulp and paper mills in Quebec, Ontario and the Atlantic provinces. ${ }^{8}$

The SLA 2006 established both a binational industry council and a softwood lumber committee. The binational industry council received about \$US 50 million to strengthen the North American lumber industry and build stronger cross-border partnerships and trust. Yet, the agreement had barely become law when the Coalition for Fair Lumber Imports complained that Canada had violated the terms of the SLA 2006 through forest industry assistance programs offered by the Ontario and Quebec governments. It also alleged that Canada in British Columbia and Ontario had violated the agreement's "surge" mechanism or the amount of volume exported over that permitted by Annex 8 of the SLA 2006. The Softwood Lumber Committee discussed these issues in February without satisfaction to the American Trade Representative. She requested formal consultations with Canada under the terms of the SLA 2006 on March 30, 2007. If the matter is not resolved, either party may refer the matter to arbitration under the rules of the London Court of International Arbitration.

This shows that the long-term trade issue in softwood lumber in North America has not gone away. In fact, it has become more complicated with new forms of quotas and taxes, new institutions, and dispute resolution pathways to contravene the ideas in the NAFTA. When all is said and done, the United States can change its trade laws while Canada and Mexico wonder what happened. Meanwhile, the current environmental situation in western North America with its droughts, fires, forest health issues and powerful conservation lobby is obviously beyond the jurisdiction of one province, state, or nation. Clearly then, the need for a comprehensive North America policy on natural resources-as advocated by Theodore Roosevelt in 1909—still exists today.

Gordon Smith, U.S. Senator from Oregon, noted on February 14, 2006, "We can continue along the path of a patchwork of tariffs and quotas, or we can seek to resolve the differences in our lumber systems. We can continue to act as two countries with two markets, or we can proceed as one continent with a shared market that abides by the same market rules." Along with that shared market, there is a shared ecology. The state of Oregon has an ecology more resembling British Columbia than Georgia. Canada and Mexico are much closer to certain American markets than are regions in the United States. A primary industry like forest products cannot ignore geographic and environmental factors. Any continental policy on forest resources has to recognize the need to reconcile issues with the environment and trade in the calculus.

Further, there is an emerging body of evidence that in some regions of western North America, there has been a revival of deliberative democracy. Not just public participation but members of the community are empowered or take power. Under this approach, the purpose of politics is not simply to divide spoils according the pre-given preferences

\footnotetext{
${ }^{8}$ http://www.cec.org/home/index.cfm?varlan=english. Accessed April 2, 2007.

${ }^{9}$ http://gsmith.senate.gov/public/index.cfm?FuseAction=Press Releases.Detail\&PressRelease_id $=192 \&$ Month $=2 \&$ Year $=2006$. Accessed April 2, 2007.
}

and power of interest groups but rather to develop shared understandings of the common good through public deliberation (Baker and Kusel 2003). In the case of western North America, the common good that is being sought is the desired future forest condition along with fair trading arrangements. This approach encourages participation but also brings legitimacy to the decision about the resource debate.

A form of participatory democracy could be effectively used in the softwood issue among the three countries to determine a shared vision of future trade conditions in softwood lumber and forest products trade as a whole. It could be used to examine the environmental impacts of trade. Turner et al. (2005) discussed three conflicting environmental effects of freer trade: composition, scale, and technique. The composition effect is the change in the mix of products that each country produces, which depends on each country's comparative advantage. They argue that the scale effect increases income resulting in higher consumption and associated increases in production and deforestation. Increased incomes also result in greater demand for the conservation of forests. This is their technique effect. Sedjo and Lyon (1983) pointed out there is a major restructuring of the comparative advantage of timber production with some areas over-exploiting and degrading the forests.

A non-profit, partially governmental approach that could be termed the continental forest and forest management chamber could be formed either from the institutions presently involved or from delegates from the countries. The chamber would use a deliberative form of democracy. In this deliberative form each delegate would have a moral right to participate equally in developing forest conservation and trade policies for the benefit of the whole continental society. Posner (2003) discussed the moral duties that accompany moral rights and lists the following:

1) Have sufficient interest and knowledge to participate intelligently in deliberations,

2) Discuss issues in an open-minded manner with other delegates, and

3) Base opinions and actions, after deliberation, of what is best for the society and the countries as a whole, not on narrow self-interest.

Membership in the chamber would be civic-minded and oriented to the public interest. Delegates would be both informed and not be in conflict of interest. Recommended policies and institutional arrangements would emerge from deliberation among these delegates. Of course, the dialogue would not be between lawyers representing special interests but participants from the three countries and representing all levels of the product chain, inclusive rather than exclusive, searching for a common vision for the forests resources of North America.

\section{Conclusion}

A recommendation of the 1909 North American Conservation Conference was that, "conservation of natural resources on the continent of North America is of such a nature and of such general importance that it should be world-wide in its scope." That theme was also developed in Rio de Janeiro in 1992 when Canada's Prime Minister announced a \$Cdn 10 million donation of start-up funds for a program to empower communities and interest groups to view forests within the wider concept of ecosystem manage- 
ment and take a landscape approach to forest planning. The upshot of that commitment was an international model forest network with some 40 such forests in 19 countries, many encouraging types of participatory democracy in terms of their decision-making. While the preservation/human intervention dichotomy has polarized and paralyzed forest decision-making as much as the softwood trade issue has stymied real economic progress in the North American solid wood products industries, the ideas embedded in the international model forest system were revolutionary-but are they applicable to something as large as a continent?

The North American Free Trade Agreement seemed to promise a sustainable trade regime on the continent and it had an environmental side. Yet there were conflicting purposes of the Agreement. In the area of fossil fuel development NAFTA permitted and even encouraged the subsidies that are at times both damaging to the economy and the environment. Meanwhile the controversy over similar subsidies in the trade of softwood lumber raged. With the SLA 2006 there will be revenues in the form of taxes, which could be used to fund the Canadian chapter of the North American Chamber. For the first quarter of 2007 in British Columbia these are estimated to be $\$$ US158 million. ${ }^{10}$ It would be encouraging to think that the public interest was somewhat enhanced by the softwood controversy. Many ecological problems resulting from the wrong harvesting practice could be corrected with this sum of money. Of course, that is not what the softwood lumber controversy was all about.

To quote Noam Chomsky, "The most effective way to restrict democracy is to transfer decision-making from the public arena to unaccountable institutions: kings and princes, priestly castes, military juntas, party dictatorships, or modern corporations." 11 Before trade laws and lawyers push issues like trade in softwood lumber to untold limits, it is time to bring deliberations out the boardroom and into a public forum to involve the individuals that are actually being impacted by policy formulation-citizens! Let them help deliberators in creating a shared vision of a true North American community of fair trade, markets and the forests' environmental health. Let us create the North American Chamber on Forests and Trade.

\section{Acknowledgements}

Appreciation is extended to the Canadian Forest Service for the use of the two figures, Relative GDP and Price Wedge, in this paper.

\section{References}

Baker, M. and J. Kusel. 2003. Community forestry in the United States. Island Press, Washington, DC. 247 p.

Baumgartner, D.W., R.G. Krebill, J.T. Arnott and G.F. Weetman. 1985. Lodgepole pine: the species and its management. Cooperative Extension, Washington State University, Pullman, WA. 381 p. Campbell, B. 2005. Time to draw a line in the sand: NAFTA and the softwood lumber dispute. Briefing Paper Volume 6, No.1, Canadian Centre for Policy Alternatives, Ottawa.

\footnotetext{
${ }^{10}$ Calculation made from data from: http://www.for.gov.bc.ca/ HET/Softwood/2006\%20SWL\%20Surge\%20\&\%20Tax\%20Rate\% 20Monitoring.htm. Accessed June 20, 2007.

${ }^{11} \mathrm{http}$ ///www.thirdworldtraveler.com/Chomsky/Chomsky_quotes. html. Accessed June 15, 2007
}

Clawson, M. 1985. The future of public forests in the Pacific Northwest. The Starker Lectures, College of Forestry, Oregon State University, Corvallis, OR.

Department of Commerce (DOC). 2003. Proposed analytical framework, softwood lumber from Canada. Washington, DC.

Galbraith, J.K. 1985. Anatomy of power. Houghton Mifflin Co., Boston, MA. 206 p.

Hays, S.P. 1959. Conservation and the gospel of efficiency: the progressive conservation movement, 1890-1920. Harvard University Press, Cambridge, MA. 297 p.

Julius, D. 2005. US economic power: waxing or waning? Harvard International Review 26(4): 14-18.

Leslie, P. 1997. Governing the economy within economic unions: Canada, The EU and the NAFTA. Paper presented to workshop "North American Federalism and NAFTA: Three Perspectives" April 27-29, 1997, University of California at Berkeley. Available at http://ias.berkeley.edu/canada/fedweb.htm [accessed June 15, 2007]. McCarl, A.B. and R.W. Haynes. 1985. Exchange rate influence softwood lumber trade. Journal of Forestry 83(6): 368-370.

Perry, D.A 1998. The scientific basis of forestry Annual Review of Ecological and Systematics 29(1): 435-466.

Pinchot, G. 2001. Conservation as a foundation of permanent peace. Reprinted in Forest History Today /Spring/Fall 2001 from Nature August 10, 1940, Volume 146, No. 3693: 183-185.

Posner, R.A. 2003. Law, pragmatism and democracy. Harvard University Press, Cambridge, MA. 398 p.

Roff. R.J., A. Krajnc and S. Clarkson. 2003. The conflicting economic and environmental logics of North American Governance: NAFTA, energy subsidies, and the environment. Second North American Symposium of Assessing the Environmental Effects of Trade. Commission for Environmental Cooperation, Montreal, Quebec. Available on-line at http://www.cec.org/files/pdf/ECONOMY/Rofffinal_en.pdf.

Rothschild, K.W. 2002. The absence of power in contemporary economic theory. Journal of Socio-economics 31: 433-442.

Sedjo, R.A. and K.S. Lyon. 1983. Long-term forest resources trade, global timber supply, and intertemporal comparative advantage. American Journal of Agricultural Economics 65 (5): 1010-1016.

Smith, W.B., J.S. Vissage, D.R. Darr and R.M. Sheffield. 2000. Forest Resources of the United States, 1997. U.S. Department Agriculture Forest Service, St. Paul, MN

South, D.B and E.R. Buckner. 2003. The decline of the southern yellow pine timberland. Journal of Forestry 101(1): 30-35.

Stennes, B. and B. Wilson. 2005. An Analysis of Lumber Trade Restrictions in North America: Application of a Spatial Equilibrium Model. Forest Policy and Economics 7: 297-308.

Turner, J.A, J. Buongiorno and S. Zhu. 2005. Effects of the free trade area of Americas on forest resources. Agricultural and Resource Economics Review 34(1): 104-118.

Wear, D.N. and K.J. Lee. 1993. U.S. policy and Canadian lumber: effects of the 1986 memorandum of understanding Forest Science 39 (4): 799-815.

Westoby, J. 1987. The purpose of forests. Basil Blackwell Ltd., Oxford, UK. 343 p.

Xiang, Q and R. Yin . 2006. Impact of Globalization and Policy Change on United States Softwood Lumber Trade. Forest Science Volume 52, Number 4: 381-389.

Zhang, D. 2001. Welfare impacts of the 1996 US-Canada softwood lumber (trade) agreement. Canadian Journal of Forest Research 31(11): 1958-1967. 